\title{
Editorial: a practical paediatric neuroradiology guide for trainees and fellows
}

When the editors of the journal Translational Paediatrics asked me to supervise a paediatric neuroradiology series and I started to think about possible topics, the moment that came into my mind was my first night as a neuroradiology fellow in Toronto SickKids hospital back in 2014.

I remembered an urgent neonatal MRI scan coming overnight, in the images there were small, foci of abnormal signal, T2 hypointense, T1 hyperintense with some restriction. I called my supervisor and told her "they don't look like infarctions, I think these are multiple abscesses".

She did not correct me, she just said "I am sending you a couple of papers, have a look and let me know what you think". These were papers on punctate white matter lesions of the infant, something I had never heard before.

The name of my supervisor that night was Dr. Helen Branson and she taught me something very important that night: no matter how much you read if you don't know what papers have real value, and that this is the importance of an experienced guide, to give you something you can't find just reading everything coming out in literature.

In other words, our efforts as lifelong students should be in finding and teaching the right things to know in order to become better radiologists.

So, I asked myself "what a trainee starting a paediatric neuroradiology fellowship would need to know as starting point to build her/his long-lasting knowledge?”.

The answer was not just another series with paediatric neuroradiology topics but a series of introductive papers from experts about the basic approach to different fields of this fascinating area of paediatric radiology.

What are the most recognisable and clinically useful radiological patterns of neurometablolic and neurogenetic disorders? How to approach radiologically a child with epilepsy and what are the differences with other clinical indications? What are the basics of cranial ultrasound, spectroscopy and foetal imaging? How to recognise and interpret post-neurosurgical changes? How to become a good manager in radiology? How to differentiate main paediatric brain tumours?

These are some of the questions we tried to answer in this specialised series, which was conceived as a practical paediatric neuroradiology guide for trainees and fellows?

I would like to thank the many experts who find the time in this difficult moment to write up such comprehensive papers and many patients and families in our children's hospitals around the world.

\section{Acknowledgments}

Funding: None.

\section{Footnote}

Provenance and Peer Review: This article was commissioned by the editorial office, Translational Pediatrics for the series "Pediatric Neuroradiology for Trainees and Fellows: An Updated Practical Guide". The article did not undergo external peer review.

Conflicts of Interest: The author has completed the ICMJE uniform disclosure form (available at http://dx.doi.org/10.21037/ tp-21-91). The series "Pediatric Neuroradiology for Trainees and Fellows: An Updated Practical Guide" was commissioned by the editorial office without any funding or sponsorship. Felice D'Arco served as the unpaid Guest Editor of the series and serves as an unpaid editorial board member of Translational Pediatrics from Sep 2019 to Oct 2021. Felice D'Arco reports unrelated payments for serving as expert in court, lecturing and private radiology reporting.

Ethical Statement: The author is accountable for all aspects of the work in ensuring that questions related to the accuracy or integrity of any part of the work are appropriately investigated and resolved. 
Open Access Statement: This is an Open Access article distributed in accordance with the Creative Commons AttributionNonCommercial-NoDerivs 4.0 International License (CC BY-NC-ND 4.0), which permits the non-commercial replication and distribution of the article with the strict proviso that no changes or edits are made and the original work is properly cited (including links to both the formal publication through the relevant DOI and the license). See: https://creativecommons.org/licenses/by-nc$\mathrm{nd} / 4.0 \%$.

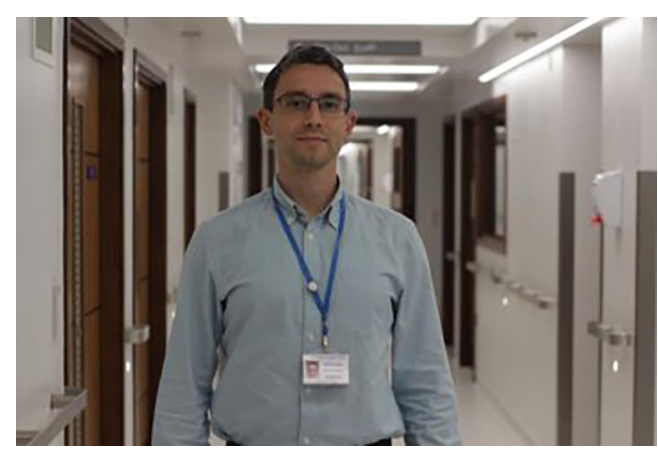

Felice D'Arco

Felice D'Arco, MD Consultant Neuroradiologist, Great Ormond Street Hospital for Children NHS Foundation Trust, London, UK (Email: darcofel@gmail.com) Submitted Mar 07, 2021. Accepted for publication Mar 17, 2021. doi: $10.21037 /$ tp-21-91 View this article at: http://dx.doi.org/10.21037/tp-21-91

Cite this article as: D'Arco F. Editorial: a practical paediatric neuroradiology guide for trainees and fellows. Transl Pediatr 2021;10(4):1063-1064. doi: 10.21037/tp-21-91 